\title{
Unplanned antiretroviral treatment interruptions in southern Africa: how should we be managing these?
}

\author{
Nina Veenstra ${ }^{*}$, Alan Whiteside ${ }^{1}$, David Lalloo², Andrew Gibbs ${ }^{1}$
}

\begin{abstract}
Adherence to antiretroviral therapy is essential for maximising individual treatment outcomes and preventing the development of drug resistance. It is, however, frequently compromised due to predictable, but adverse, scenarios in the countries most severely affected by HIV/AIDS. This paper looks at lessons from three specific crises in southern Africa: the 2008 floods in Mozambique, the ongoing political and economic crisis in Zimbabwe, and the 2007 public sector strike in South Africa. It considers how these crises impacted on the delivery of antiretroviral therapy and looks at some of the strategies employed to mitigate any adverse effects. Based on this it makes recommendations for keeping patients on treatment and limiting the development of drug resistance where treatment interruptions are inevitable.
\end{abstract}

\section{Review}

Antiretroviral therapy (ART) adherence is compromised under some situations in countries most heavily affected by HIV/AIDS. A frequently cited meta-analysis affirmed that patients in sub-Saharan Africa (sSA) record adherence levels as good as those documented in the rich world [1]. However, unfavourable contexts limit an individual's control over their own treatment.

Many early ART programmes which were the subject of adherence studies in sSA captured a set of circumstances that cannot consistently be maintained in the longer-term as treatment is scaled up. In particular, inconsistent drug supplies have been shown to be an important factor influencing adherence [see for example [2-5]]. Both direct and indirect costs, a function of the broader socioeconomic environment, also feature prominently in relevant research [see for example [6-10]].

Any threats to ART adherence need to be taken seriously if we are to optimise treatment outcomes for individuals. Robust evidence exists on the effect of adherence on viral load [11-15], the immune system [16-18], and clinical prognosis [16,19-23]. Most importantly perhaps, the increased risks of illness and death

\footnotetext{
* Correspondence: veenstran@ukzn.ac.za

${ }^{1}$ Health Economics and HIV/AIDS Research Division, Westville Campus, University of KwaZulu-Natal, Durban, South Africa
}

amongst those that are poorly adherent are undeniable. A recent study in South Africa concluded those patients claiming less than $80 \%$ of their prescription refills were over three times more likely to die than those claiming more than $80 \%$ [21].

The development of drug resistance due to poor adherence goes beyond the individual level. It becomes a public health issue when drug resistant viral strains are transmitted and this has been a major concern amongst governments and health agencies. As treatment was introduced in SSA, we were warned of a situation of 'antiretroviral anarchy' where the rapid emergence and transmission of resistant viral strains would ultimately limit treatment options [24]. Fortunately, transmitted resistance in countries in sSA currently scaling up ART programmes is still less than $5 \%$, but needs to be monitored closely [25]; increasing levels of resistance are inevitable as treatment coverage expands. With nonnucleoside reverse transcriptase inhibitor (NNRTI)-regimens in particular (used most commonly in sSA), drug resistance can develop after unplanned treatment interruptions of just a few days [26,27].

This article looks at ART adherence concerns arising from three specific crises in the southern African region, based on a literature review of reports and papers in the public domain. It considers the impact of these crises on adherence and explores strategies to try and keep 
patients on treatment, or to interrupt their treatment safely. It uses this as a basis for making suggestions as to how ART interruptions arising from various scenarios might be avoided and managed in future.

\section{What types of situations compromise ART adherence and how does this happen?}

There are a huge range of different crises that can potentially undermine ART treatment in southern Africa and the broader region. These crises are of different natures, various durations (short term vs long term) and vary in geographical extent (localised vs widespread). They also manifest in different ways. This paper looks at problems with health system functioning and ART delivery during: 1) the 2008 floods in Mozambique, 2) the ongoing political and economic crisis in Zimbabwe, and 3) the 2007 public sector strike in South Africa (see Table 1). While each crisis is irrefutably unique in many ways, we have used some of the obviously classifiable features to frame the recommendations.

In the case of natural disasters (and particularly floods), health concerns are often dominated by sanitary problems and overcrowding in temporary camps, which increase the risks of diarrhoeal diseases, cholera, measles, and malaria [28]. In Mozambique reports suggested that 72 people died of cholera and an equal number of other waterborne diseases, a number far greater than the dozen or so that died as a result of rising flood waters [29]. The immediate need to intervene with safe access to clean water meant that other health problems were eclipsed. Some longer term risks were however identified, including: 1) poor access to food supplies, potentially resulting in malnutrition, and 2) poor access to health care, potentially resulting in worse maternal and child health outcomes and inadequate management of both acute and chronic diseases [30].

Situations that results in the displacement of large numbers of people means those on ART may not be able to access the medication they require. In Mozambique, fleeting mention was made in a few reports of the poor access to health facilities in resettlement areas, and the fact that health posts (providing very basic services) in these camps were slow to open due to a lack of drugs $[31,32]$. Medecins Sans Frontiers reported in late
January 2008 that 60 patients in Mutarara (Tete province) on HIV and TB treatment were missing and had not come to the hospital to collect their monthly medication [33]. In this instance teams were sent out to find them, but public health services do not generally have the capacity to respond in this way.

Political and economic failure, which has widespread implications for the health system, is harder to manage and control for. Health care provision can become more difficult due to the lack of drugs and medical supplies, as well as insufficient numbers of health workers. In Zimbabwe this resulted in the closure of some of the largest hospitals in late 2008 [34]. Even where drugs were free and health services available, patients struggled to access them due to obstacles such as high fuel and transport costs [35]. Under such circumstances patients can't afford all the basic necessities and are forced to migrate, with deleterious consequences for treatment.

How do health workers and ART patients respond to such a chaotic situation and are these responses appropriate? In Zimbabwe there were reports of ART patients missing drug doses, sharing drugs, selling their drugs and changing regimens to try and cope with inadequate drug supplies and poor economic circumstances, so fuelling concerns of a drug-resistant HIV epidemic $[34,36,37]$. On a more positive note, aid agencies and donors were aware of the need to keep patients on treatment and played an important role in ensuring the provision of drug supplies for the ART programme.

The category of health system or service failure is all encompassing as it can manifest in many ways, with common examples including health worker strikes or drug stock-outs. Such problems are often symptomatic of broader political and/or economic collapse, although here we concern ourselves primarily with shorter term failures that are more confined to the health sector. These generally result in patients not accessing necessary health services for a limited period of time, as was the case during the month-long South African public sector strike in 2007. In this instance there were mixed reports over the extent of the disruption, but a significant number of patients with HIV/AIDS and TB could not obtain their treatment because of clinic closures $[38,39]$.

Table 1 Three crises in southern Africa that have impacted on ART adherence

\begin{tabular}{|c|c|c|c|c|}
\hline Nature of crisis & Case study & Major effect of crisis & Duration of crisis & Extent of crisis \\
\hline 1. Natural disasters & $\begin{array}{l}2008 \text { floods in } \\
\text { Mozambique }\end{array}$ & $\begin{array}{l}\text { Migration, damage to health } \\
\text { system infrastructure }\end{array}$ & Short to medium term & Localised \\
\hline $\begin{array}{l}\text { 2. Political and } \\
\text { economic failure }\end{array}$ & $\begin{array}{l}\text { Ongoing situation in } \\
\text { Zimbabwe }\end{array}$ & $\begin{array}{l}\text { Poverty, migration, health } \\
\text { system collapse }\end{array}$ & Long term & Widespread \\
\hline $\begin{array}{l}\text { 3. Health service or } \\
\text { system failure }\end{array}$ & $\begin{array}{l}2007 \text { public sector } \\
\text { strike in South Africa }\end{array}$ & Poor access to health services & $\begin{array}{l}\text { Short term (but similar nature } \\
\text { crises can be longer term) }\end{array}$ & $\begin{array}{l}\text { Widespread (but similar nature } \\
\text { crises can be localised) }\end{array}$ \\
\hline
\end{tabular}


As the duration of the public sector strike was short term, patients with buffer drug stocks would have possibly been able to weather the crisis with little disruption to treatment. However, in most cases patients only obtain their drugs on a month by month basis and so would have had little reserve. The Southern African HIV Clinicians Society took the initiative of issuing a press statement on how treatment interruptions should be dealt with. This essentially advised patients to seek help from other sources (either private pharmacies or another hospital/clinic) and to stop all drugs simultaneously if need be, without decreasing the dose to make treatment last longer [40]. Unfortunately, due to its late release in media that few have access to and because it was written in English, it is unlikely that this information would have reached many of the ART patients who needed it.

\section{What strategies should be considered to keep ART patients adherent on treatment?}

The two key messages from this review are: 1) we need to plan for and manage various crises impacting on ART delivery; and 2) there are a number of strategies that have been employed and should be evaluated. Unfortunately, most of what has been tried to date has been 'too little, too late' and there has been almost no indication as to its effectiveness. Nonetheless, there are conclusions and recommendations arising from the review that provide a starting point.

Management strategies will vary according to the duration of the crisis. Many shorter term crises like those reviewed in this paper can be anticipated, indicating a need for sound planning and preparedness. Patients could be given extra drug supplies to tide them over a potentially difficult time. Anecdotal evidence suggests that this strategy is used to help patients cope with short periods of planned migration. It does, however, come with the concern that relaxing controls on ART might result in drugs being shared or sold on the black market. It therefore has to be managed carefully.

Longer term crises, in contrast, cannot be planned for so easily because of the chronic erosion to the health system and the time taken to potentially restore services. In these cases, close monitoring and proactive management is needed to alleviate the effects of the crisis on patient treatment, care and support. Health information systems are central; needing to be sensitive enough to alert managers to change (such as when fewer patients start presenting for follow up or drug shortages are imminent) and detailed enough to give a fairly complete picture of what is happening. Our observation that so little information exists on the impact of crises on ART programmes, is testament to how poor such systems currently are. It is therefore no surprise that management of disruptions to ART delivery is largely ineffective. Looking beyond the crisis itself, a carefully designed recovery plan will assist in restoring health system functioning as quickly as possible.

Just as shorter term crises will be easier to weather than longer term crisis, so too will localised disruptions compared to widespread upheaval. Careful management and some reorganisation of services may suffice with localised disruptions. There was some evidence of this happening in Mozambique, where new health posts were set up and community workers used to search for patients [31]. Such strategies do, however, have to be implemented quickly and efficiently if they are to ensure patient adherence to medication. The use of mobile phones to keep contact with patients could be explored.

Widespread upheaval on the other hand, requires an increased involvement and co-ordination of health sector partners, be they private, donor, NGO or faith based. There were indications from Zimbabwe that such partners played an important role in ensuring the continuation of ART drug supplies, despite operating in a hostile environment where drug delivery and distribution were problematic [34]. In South Africa private health care providers took care of many Intensive Care Unit (ICU) patients during the strike [41]. In a country like this, where the private health sector is large, there is scope for exploring partnerships that could benefit a wider range of patients in times of crisis.

Crises that are both widespread and longer term, like that in Zimbabwe, often require a particularly holistic approach to support patients on ART. This is because the socio-economic circumstances of households become compromised, meaning that simply ensuring ongoing service delivery is not sufficient to maintain ART adherence. In such cases extra assistance may be required from a range of partners to manage the indirect costs of seeking care, such as transport costs, and to avoid a situation where people are having to trade-off basic necessities.

For all types of crisis, whether long or short term, widespread or localised, patient information systems which facilitate tracking and enable patients to collect their drugs from multiple locations would help tremendously. This is because migration is often a common outcome of a crisis. Even in South Africa, where patients did not migrate during the strike, they were advised to try and source their medication from other health facilities or private pharmacies [40]. However, patients do not carry any record of their medication on them and so were told to take their pills along instead for the doctor or pharmacist to identify, which obviously is not ideal.

Lastly, the impact of deficient ART adherence during crisis situations could be lessened through attention to 
the basics - patient adherence counselling and health worker training. If adherence counselling includes discussion on what to do in case of being unable to access drugs, then it should be possible to avoid some of the inappropriate coping strategies (such as sharing drugs or reducing drug doses) reported in Zimbabwe. Clinicians properly trained in managing treatment interruptions could stagger the time at which different drug classes are stopped during drug stock-outs to avoid the development of NNRTI resistance in particular. Issuing such guidance during a crisis, as was done in South Africa [40], might supplement such measures but is unlikely to be effective on its own.

\section{Who takes responsibility?}

There is no doubt that widespread, long term crises, particularly those involving state failure and political violence (such as in Zimbabwe), are the greatest threat to ART adherence. In such situations there is an urgent need to consider the question of responsibility. If government failure is making it difficult for people to obtain the treatment they need and NGOs within the country are struggling to operate in a hostile environment, should there not be some international responsibility for people living with HIV/AIDS?

In addressing the situation of people living with AIDS in Zimbabwe, there is scope to consider how the emerging 'Responsibility to Protect' (RtoP) doctrine could be applied [42]. The RtoP considers that 'sovereign states bear the responsibility to protect their citizens from avoidable catastrophe, but that when they are unwilling or unable to do so, that responsibility must be borne by the broader community'[43]. It therefore sets new norms for international security and human rights.

In the case of Zimbabwe, many patients on ART struggled to access their treatment not only within the country's borders, but because they were forced to migrate to neighbouring countries, especially South Africa. Undocumented migrants in South Africa have a constitutional right to access ART, but many remain unable to do so [44]. Furthermore, one can argue that these 'migrants' are in fact refugees, in which case the role of the United Nations High Commissioner for Refugees (UNHCR) in supporting access and adherence to ART comes into question. The UNHCR has pledged to keep HIV/AIDS as priority [45], however it is unclear what is being done in this regard.

\section{Conclusions}

In conclusion, ART programmes in sSA will continue to be challenged by a range of different crises. What we have seen to date is that the need to prioritise often results in immediate concerns arising from such crises eclipsing those with longer-term consequences. HIV/
AIDS is by nature a long-term disease and failure to maintain treatment coverage and adherence will not immediately result in large numbers of deaths. Unfortunately this does not mean that the consequences will be less severe only that they will play out for years to come. Responding strategically to the various threats posed by a crisis calls for careful consideration and co-ordination, rather than a knee-jerk response. Ultimately, how we plan for and manage such crises could strongly influence treatment outcomes in the years and decades to come.

\section{Author details}

${ }^{1}$ Health Economics and HIV/AIDS Research Division, Westville Campus, University of KwaZulu-Natal, Durban, South Africa. ${ }^{2}$ Liverpool School of Tropical Medicine, Pembroke Place, Liverpool, UK.

\section{Authors' contributions}

NV contributed to the design of the study, undertook the literature review and was primarily responsible for drafting the manuscript. AW conceptualised the design of the study and helped with revising the manuscript for publication. DL conceptualised the design of the study and helped with revising the manuscript for publication. AG helped with revising the manuscript for publication. All authors read and approved the final manuscript.

\section{Competing interests}

The authors declare that they have no competing interests.

Received: 13 October 2009 Accepted: 31 March 2010

Published: 31 March 2010

\section{References}

1. Mills EJ, Nachega JB, Buchan I, Orbinski J, Attaran A, Singh S, Rachlis B, Wu P, Cooper C, Thabane L, Wilson K, Guyatt GH, Bangsberg DR: Adherence to antiretroviral therapy in sub-Saharan Africa and North America: a meta-analysis. Journal of the American Medical Association 2006, 296:679-690.

2. Hawkins C, Murphy R: Adherence to antiretroviral therapy in resourcelimited settings: everything matters. AIDS 2007, 21:1041-1042.

3. Iliyasu Z, Kabir M, Abubakar IS, Babashani M, Zubair ZA: Compliance to antiretroviral therapy among AIDS patients in Aminu Kano Teaching Hospital, Kano, Nigeria. Nigerian Journal of Medicine 2005, 14:290-294.

4. van Oosterhout JJ, Bodasing N, Kumwenda JJ, Nyirenda C, Mallewa J, Cleary PR, de Baar MP, Schuurman R, Burger DM, Zijlstra EE: Evaluation of antiretroviral therapy results in a resource-poor setting in Blantyre, Malawi. Trop Med Int Health 2005, 10:464-470.

5. Laurent C, Meilo H, Guiard-Schmid JB, Mapoure Y, Noel JM, M'Bangue M, Joko A, Rozenbaum W, Ntone FN, Delaporte E: Antiretroviral therapy in public and private routine health care clinics in Cameroon: lessons from the Douala antiretroviral (DARVIR) initiative. Clin Infect Dis 2005, 41:108-111.

6. Hardon AP, Akurut D, Comoro C, Ekezie C, Irunde HF, Gerrits T, Kglatwane J, Kinsman J, Kwasa R, Maridadi J, Moroka TM, Moyo S, Nakiyemba A, Nsimba S, Ogenyi R, Oyabba T, Temu F, Laing R: Hunger, waiting time and transport costs: time to confront challenges to ART adherence in Africa. AIDS Care 2007, 19:658-665

7. Weiser S, Wolfe W, Bangsberg D, Thior I, Gilbert P, Makhema J, Kebaabetswe P, Dickenson D, Mompati K, Essex M, Marlink R: Barriers to antiretroviral adherence for patients living with HIV infection and AIDS in Botswana. J Acquir Immune Defic Syndr 2003, 34:281-288.

8. Byakika-Tusiime J, Oyugi JH, Tumwikirize WA, Katabira ET, Mugyenyi PN, Bangsberg DR: Adherence to HIV antiretroviral therapy in HIV+ Ugandan patients purchasing therapy. Int J STD AIDS 2005, 16:38-41.

9. Ramadhani $\mathrm{HO}$, Thielman NM, Landman KZ, Ndosi EM, Gao F, Kirchherr JL, Shah R, Shao HJ, Morpeth SC, MCNeill JD, Shao JF, Bartlett JA, Crump JA: Predictors of incomplete adherence, virologic failure, and antiviral drug 
resistance among HIV-infected adults receiving antiretroviral therapy in Tanzania. Clin Infect Dis 2007, 45:1492-1498.

10. Mills EJ, Nachega JB, Bangsberg DR, Singh S, Rachlis B, Wu P, Wilson K, Buchan I, Gill CJ, Cooper C: Adherence to HAART: a systematic review of developed and developing nation patient-reported barriers and facilitators. PLoS Med 2006, 3:e438.

11. Gross R, Yip B, Lo Re V, Wood E, Alexander CS, Harrigan PR, Bangsberg DR, Montaner JS, Hogg RS: A simple, dynamic measure of antiretroviral therapy adherence predicts failure to maintain HIV-1 suppression. J Infect Dis 2006, 194:1108-1114.

12. Liu H, Miller LG, Hays RD, Golin CE, Wu T, Wenger NS, Kaplan AH: Repeated measures longitudinal analyses of HIV virologic response as a function of percent adherence, dose timing, genotypic sensitivity, and other factors. J Acquir Immune Defic Syndr 2006, 41:315-322.

13. Maggiolo F, Ravasio L, Ripamonti D, Gregis G, Quinzan G, Arici C, Airoldi M, Suter F: Similar adherence rates favor different virologic outcomes for patients treated with nonnucleoside analogues or protease inhibitors. Clin Infect Dis 2005, 40:158-163.

14. Nachega JB, Hislop M, Dowdy DW, Chaisson RE, Regensberg L, Maartens G: Adherence to nonnucleoside reverse transcriptase inhibitor-based HIV therapy and virologic outcomes. Ann Intern Med 2007, 146:564-573.

15. Robbins GK, Daniels B, Zheng H, Chueh H, Meigs JB, Freedberg KA: Predictors of antiretroviral treatment failure in an urban HIV clinic. J Acquir Immune Defic Syndr 2007, 44:30-37.

16. Kitahata MM, Reed SD, Dillingham PW, Van Rompaey SE, Young AA, Harrington RD, Holmes KK: Pharmacy-based assessment of adherence to HAART predicts virologic and immunologic treatment response and clinical progression to AIDS and death. Int J STD AIDS 2004, 15:803-810.

17. Mannheimer S, Friedland G, Matts J, Child C, Chesney M: The consistency of adherence to antiretroviral therapy predicts biologic outcomes for human immunodeficiency virus-infected persons in clinical trials. Clin Infect Dis 2002, 34:1115-1121.

18. Wood E, Hogg RS, Yip B, Harrigan PR, O'Shaughnessy MV, Montaner JS: The impact of adherence on CD4 cell count responses among HIV-infected patients. J Acquir Immune Defic Syndr 2004, 35:261-268.

19. Garcia de Olalla P, Knobel H, Carmona A, Guelar A, Lopez-Colomes IL, Cayla JA: Impact of adherence and highly active antiretroviral therapy on survival in HIV-infected patients. J Acquir Immune Defic Syndr 2002, 30:105-110.

20. Hogg RS, Heath K, Bangsberg D, Yip B, Press N, O'Shaughnessy MV, Montaner JS: Intermittent use of triple-combination therapy is predictive of mortality at baseline and after 1 year of follow-up. AIDS 2002, 16:1051-1058.

21. Nachega JB, Hislop M, Dowdy DW, Lo M, Omer SB, Regensberg L, Chaisson RE, Maartens G: Adherence to highly active antiretroviral therapy assessed by pharmacy claims predicts survival in HIV-infected South African adults. J Acquir Immune Defic Syndr 2006, 43:78-84.

22. Stringer JS, Zulu I, Levy J, Stringer EM, Mwango A, Chi BH, Mtonga V, Reid S, Cantrell RA, Bulterys M, Saag MS, Marlink RG, Mwinga A, Ellerbrock TV, Sinkala M: Rapid scale-up of antiretroviral therapy at primary care sites in Zambia: feasibility and early outcomes. Journal of the American Medical Association 2006, 296:782-793.

23. van Sighem Al, Wiel van de MA, Ghani AC, Jambroes M, Reiss P, Gyssens IC, Brinkman $\mathrm{K}$, Lange JM, de Wolf F: Mortality and progression to AIDS after starting highly active antiretroviral therapy. AIDS 2003, 17:2227-2236.

24. Harries AD, Nyangulu DS, Hargreaves NJ, Kaluwa O, Salaniponi FM: Preventing antiretroviral anarchy in sub-Saharan Africa. The Lancet 2001, 358:410-414.

25. Bennett DE, Myatt M, Bertagnolio S, Sutherland D, Gilks CF: Recommendations for surveillance of transmitted HIV drug resistance in countries scaling up antiretroviral treatment. Antivir Ther 2008, 13(Suppl 2):25-36.

26. Oyugi JH, Byakika-Tusiime J, Ragland K, Laeyendecker O, Mugerwa R, Kityo C, Mugyenyi P, Quinn TC, Bangsberg DR: Treatment interruptions predict resistance in HIV-positive individuals purchasing fixed-dose combination antiretroviral therapy in Kampala, Uganda. AIDS 2007, 21:965-971.

27. Spacek LA, Shihab HM, Kamya MR, Mwesigire D, Ronald A, Mayanja $H$, Moore RD, Bates M, Quinn TC: Response to antiretroviral therapy in HIV-infected patients attending a public, urban clinic in Kampala, Uganda. Clin Infect Dis 2006, 42:252-259.
28. Ahern M, Kovats RS, Wilkinson P, Few R, Matthies F: Global health impacts of floods: epidemiologic evidence. Epidemiol Rev 2005, 27:36-46.

29. Lang S: Mozambique: officials master floods - but battle to contain diseases that follow. Inter Press Senvice News Agency 2008 [http://ipsnews. net/news.asp?idnews=42207].

30. World Health Organisation: Health actions during flooding in southern Africa. Southern African Humanitarian Crisis Situation Reports 2008.

31. Inter-Agency Standing Committee: Mozambique: health rapid needs assesssment in flood affected areas summary report 15-19 Jan 2008. Relief Web 2008 [http://www.reliefweb.int/rw/RWFiles2008.nsf/ FilesByRWDocUnidFilename/EGUA-7BCLX9-full_report.pdf/\$File/full_report. pdf].

32. United Nations Children's Fund: UNICEF Mozambique floods situation update 2 Feb 2008. Relief Web 2008 [http://www.reliefweb.int/rw/rwb.nsf/ db900sid/ASAZ-7CNBSE?OpenDocument].

33. Medecins Sans Frontiers: More flooding in Mozambique adds to number of displaced. MSF Article 2008 [http://www.msf.org/msfinternational/invoke. cfm?objectid=A231D8CF-15C5-F00A2581DCC184CC743F\&component=toolkit.article\&method=full_html].

34. Physicians for Human Rights: Health in ruins: a man-made disaster in Zimbabwe. Cambridge: Physicians for Human Rights 2009.

35. Medecins Sans Frontiers: Political and economic turmoil sparks healthcare crisis in Zimbabwe. MSF News and Special Reports 2007 [http://www msf.org.au/from-the-field/field-news/field-news/article/zimbabwe-politicaland-economic-turmoil-sparks-healthcare-crisis.html].

36. IRIN news: Zimbabwe: HIV-positive people floundering as economy sinks. 2006 [http://www.plusnews.org/report.aspx?reportid=39584]

37. Bodibe K: Zim health - a ticking time bomb. health-e News Service 2009 [http://www.health-e.org.za/news/article.php? uid=20032193\&PHPSESSID=8f63e05a1ce3dc2625ee52addcf14edf].

38. Alcorn K: Public service strike disrupting HIV care in South Africa. Aidsmap news 2007 [http://www.aidsmap.com/en/news/68D9B80F-C4BC4A73-93FB-2C2F1C3A146C.asp].

39. Sidley P: Strike cripples health services in South Africa. Br Med J 2007, 334:1240-1241.

40. Southern Africa HIV Clinicians Society: Press statement by the Southern African HIV Clinicians Society on interrupting antiretrovirals and other HIV-related drugs. Treatment Action Campaign Electronic Newletter 2007 [http://www.tac.org.za/community/node/2153].

41. South African Department of Health: Press release: Cost of referral of patients during public service strike. 2007 [http://www.doh.gov.za/docs/ pr-f.html].

42. Learn about the International Coalition for the Responsibility to Protect. [http://www.responsibilitytoprotect.org/index.php/about-coalition].

43. International Commission on Intervention and State Sovereignty: The Responsibility to Protect. Ottawa: International Development Research Centre 2001.

44. Human Rights Watch: Discrimination, denial, and deportation: human rights abuses affecting migrants living with HIV. New York: Human Rights Watch 2009

45. World AIDS Day: refugee agency chief pledges to keep HIV and AIDS a priority. [http://www.unhcr.org/cgi-bin/texis/vtx/search? page $=$ search\&docid $=4 \mathrm{~b} 15281 \mathrm{~b}$ g\&que]

doi:10.1186/1744-8603-6-4

Cite this article as: Veenstra et al: Unplanned antiretroviral treatment interruptions in southern Africa: how should we be managing these? Globalization and Health 2010 6:4. 